\title{
Nadir görülen bir olgu: Kikuchi-Fujimoto hastalığı
}

\author{
Mehtap PEHLiVANLAR \\ KÜÇÜK ${ }^{1}$ \\ Hayriye BEKTAŞ AKSOY ${ }^{2}$ \\ Savaş Sedat ÖZSU ${ }^{3}$ \\ Ümit ÇOBANOĞLU 4 \\ Tevfik ÖZLÜ ${ }^{3}$
}

1 Ondokuz Mayıs Üniversitesi Tıp Fakültesi, Anesteziyoloji ve Reanimasyon Anabilim Dalı, Yoğun Bakım Yan Dalı, Samsun, Türkiye

${ }^{1}$ Intensive Care Side Branch, Department of Anesthesiology and Reanimation, Faculty of Medicine, Ondokuz Mayis University, Samsun, Turkey

2 Samsun Mehmet Aydın Eğitim ve Araştırma Hastanesi, Göğüs Hastalıkları Kliniği, Samsun, Türkiye

${ }^{2}$ Clinic of Chest Diseases, Samsun Mehmet Aydin Training and Research Hospital, Samsun, Turkey

${ }^{3}$ Karadeniz Teknik Üniversitesi Tıp Fakültesi, Göğüs Hastalıkları Anabilim Dalı, Trabzon, Türkiye

${ }^{3}$ Department of Chest Diseases, Faculty of Medicine, Karadeniz Technical University, Trabzon, Turkey

${ }^{4}$ Karadeniz Teknik Üniversitesi Tıp Fakültesi, Tıbbi Patoloji Anabilim Dalı, Trabzon, Türkiye

${ }^{4}$ Department of Medical Pathology, Faculty of Medicine, Karadeniz Technical University, Trabzon, Turkey

\section{ÖZET}

\section{Nadir görülen bir olgu: Kikuchi-Fujimoto hastalığı}

Kikuchi-Fujimoto hastalı̆̆ (KFH) genellikle kendi kendini sınırlayan benign lenf nodu tutulumları ile seyreden, etyolojisi tam olarak aydınlatılamamış bir hastalıktır. Lenf nodu tutulumlarının ön planda olduğu özellikle lenfoma türü hastalıklarla karışabildiğinden ayırıIı tanı iyi yapılmalıdır. Kliniğimize halsizlik, eklem ağrıları, ateş, iştahsızlık, kilo kaybı, gece terlemesi semptomları ile başvuran 35 yaşında erkek hasta literatürler eşliğinde sunulmuştur.

Anahtar kelimeler: Kikuchi-Fujimoto hastalığı, histiositik nekrotizan lenfadenit, nedeni bilinmeyen ateş

\section{SUMMARY}

\section{A rare case: Kikuchi-Fujimoto disease}

Kikuchi-Fujimoto's disease (CFD) is a disease that usually exhibits self-limited benign lymph node involvement. Etiology of illness is not fully understood.Differential diagnosis should be performed well because lymph node involvement can be confused with lymphoma type diseases. A 35-year-old male patient with weakness, joint aches, fever, loss of appetite, weight loss, night sweating symptoms presented with the literature.

Key words: Kikuchi-Fujimoto disease, histiocytic necrotizing lymphadenitis, fever of unknown origin

\section{Yazıșma Adresi (Address for Correspondence)}

\section{Dr. Mehtap PEHLIVANLAR KÜÇÜK}

Ondokuz Mayıs Üniversitesi Tıp Fakültesi,

Anesteziyoloji ve Reanimasyon Anabilim Dalı,

Yoğun Bakım Yan Dalı, SAMSUN - TURKEY

e-mail: mehtap_phlvnlr@hotmail.com 


\section{Giriş}

Kikuchi-Fujimoto hastalığı (KFH) veya histiyositik nekrotizan lenfadenit (HNL); iyi huylu, tanısı tutulan lenf nodunun patolojik incelenmesiyle konulan, histopatolojik incelemesinde; karyorektik nükleer kalıntıları içeren, nekroz alanlarını çevreleyen lenfositik ve histiyositik hücre topluluklarına rastlanan, etyolojisi tam olarak aydınlatılamamış bir hastalıktır (1). illk kez 1972 yılında Japonya'da Kikuchi ve Fujimoto tarafından eş zamanlı tanımlanmış olup, sıklıkla genç kadınlarda 4:1 oranında sık görülmekle beraber klinik olarak özellikle servikal bölge lenf nodlarının büyümesi ve ateş ile karakterizedir (2). Ayırıcı tanıda başta lenfomalar olmak üzere malign hastalıklar, tüberküloz, sistemik lupus eritematoz ve diğer benign durumlar düşünülmelidir (3). Sıklığı tam olarak bilinmemekle beraber Uzak Doğu Asya ülkelerinde daha sık, ülkemizde nadir görülmektedir. Hastalık ortalama 1-6 ay içinde spontan olarak gerilemektedir. Kanıtlanmış ve spesifik bir tedavisi yoktur (4). Olguların yaklaşık \%3'ünde nüks görülmekte olup ciddi komplikasyonlar ve mortalite oldukça düşüktür (5).

Bu olguyu sunmaktaki amacımız klinik olarak sebebi bilinmeyen ateş ve lenfadenopati tanısıyla izlenen hastalarda, ayırıcı tanıda nadir görülen ve benign seyirli KFH'nin de hatırlanmasını sağlamaktır. Bu açıdan bakıldığında göğüs hastalıkları pratiğinde de akılda tutulması gerekli bir hastalık olarak kaydedilebilir.

\section{OLGU SUNUMU}

Otuz beş yaşında erkek hasta bir aydır halsizlik, eklem ağrıları, ara ara olan ateş yüksekliği, iştahsızlık, 1 ay içinde 10 kilo kaybı ve gece terlemesi yakınmaları ile kurumumuza başvurdu. Solunumsal yakınması olmayan hastanın dinlemekle akciğer sesleri normaldi, yapılan sistemik muayenesinde boyun sağ lojda yaklaşık $1 \mathrm{~cm}$ boyutunda ağrılı, mobil lenf nodu saptandı. Özgeçmişinde bilinen kronik bir hastalığı olmadığı, 17 paket/yılı sigara kullanımı olduğu; soy geçmişinde ise teyzesinde meme kanseri olduğu öğrenildi. Genel durumu iyi, bilinci açık, oryante ve koopere idi. PA akciğer grafisinde total vertikal uzunluk artmış, her iki kostodiyafragmatik sinüsler açık olup sağ hilus hafif dolgun görünümde idi (Resim 1). Çekilen boyun tomografisinde her iki submandibuler bez komşuluğunda, her iki ön-arka juguler zincirde yaklaşık $11 \mathrm{x}$ $10 \mathrm{~mm}$ boyutlara ulaşan round konfigürasyonlarda birkaç adet lenf nodu ve toraks bilgisayarlı tomografi (BT)'de mediastinal 1, 2, 4R-L, 7 nolu istasyonlarda büyüğü $4 R^{\prime}$ de $18 \times 17 \mathrm{~mm}$ boyutunda multipl lenf

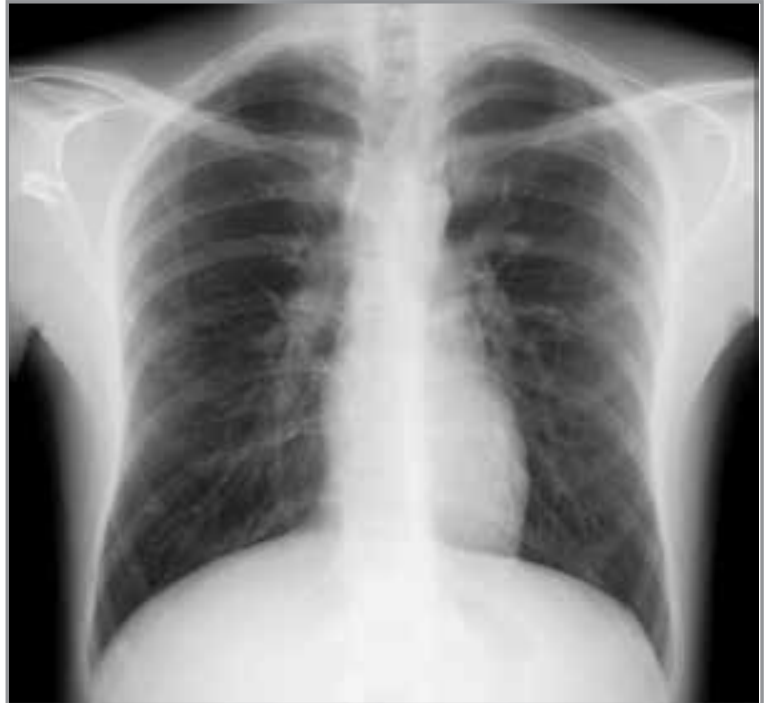

Resim 1. Hastanın başvurudaki PA akciğer grafisi.

nodları saptanan hastanın ayırıcı tanısı için tetkikleri istendi (Resim 2). Bu arada tetkikleri devam eden hastaya seftriakson, klaritromisin ve antiinflamatuvar tedaviler başlandı. Önceden de ateşli olduğu dönemlerde parasetamol preparatları ve antibiyoterapi kürleri aldı$\breve{g} ı n ı$ ifade eden hastanın genel vücut kırgınlığı ve halsizliğinin devam ettiği sorgulamadan öğrenildi.

Laboratuvar tetkiklerinde; lökosit: $4800 \times 10^{3} / \mu \mathrm{L}$, eozinofil \%0.4, Hb: $12.8 \mathrm{~g} / \mathrm{dL}$, sedimentasyon: 55 mm/saat, CRP: $6.7 \mathrm{mg} / \mathrm{dL}$, ALT: $18 \mathrm{U} / \mathrm{L}$, ALT: $32 \mathrm{U} / \mathrm{L}$, Anti-HIV: negatif, balgam ARB incelemesi negatif geldi. Yapılan tüberkülin deri testi (TDT) negatif saptandı. Sistemik lenf nodu yapan nedenleri araştırmak

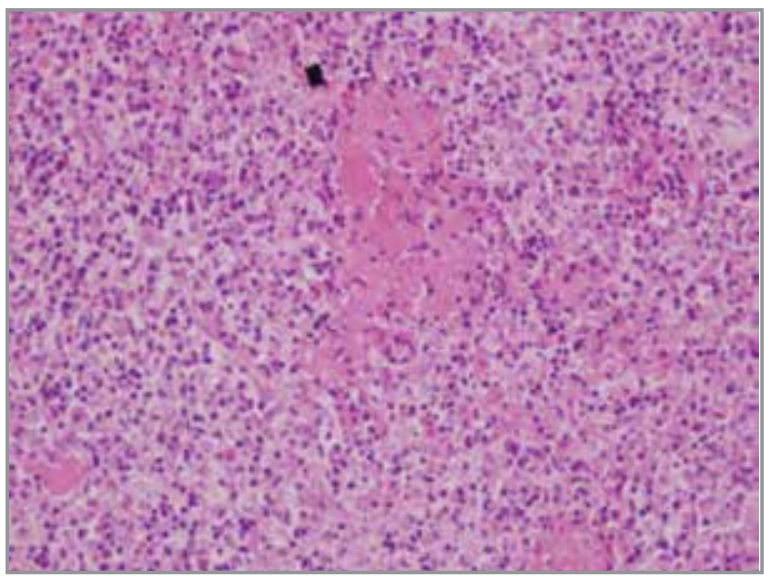

Resim 2. Patoloji kesiti. Kesitlerde nükleer fragmanlar, hücresel debriler ile apopitotik cisimcikler, nekroz ve histiyosit yığınları izlenmiştir (HE x200). 
amacı ile çekilen batın ultrasonografi (USG) normaldi, kollajen doku markerları (ANA, ANCA, anti-ds DNA), Brucella Rose Bengal testi, CMV-Rubella-Toxoplasma PCR negatifti. HSV-1 IgM sınırda pozitif, HSV-1 IgG pozitif, EBV VCA IgG ++, EBV IgM negatif saptandı. Viral solunum yolu panelinde ise C. pneumoniae IgM zayıf pozitif olup diğer parametreler negatif idi. Tiroid fonksiyon testleri normaldi. Hasta boyunda mobil lenf nodu saptanması nedeni ile tanısal amaçlı örnekleme için öncelikle kulak burun boğaz kliniğine yönlendirildi. Sağ juguler yerleşimli 1 cm'lik lenf nodu eksizyonel biyopsi patoloji sonucu histiyositik nekrotizan lenfadenit; KFH ile uyumlu olarak raporlandı (Resim 3). Nonspesifik tedaviden 20 gün sonra klinik olarak düzelen, palpabl lenf nodları regrese olan hastanın kontrol PA akciğer ve toraks BT'sinde sağ hiler lenf

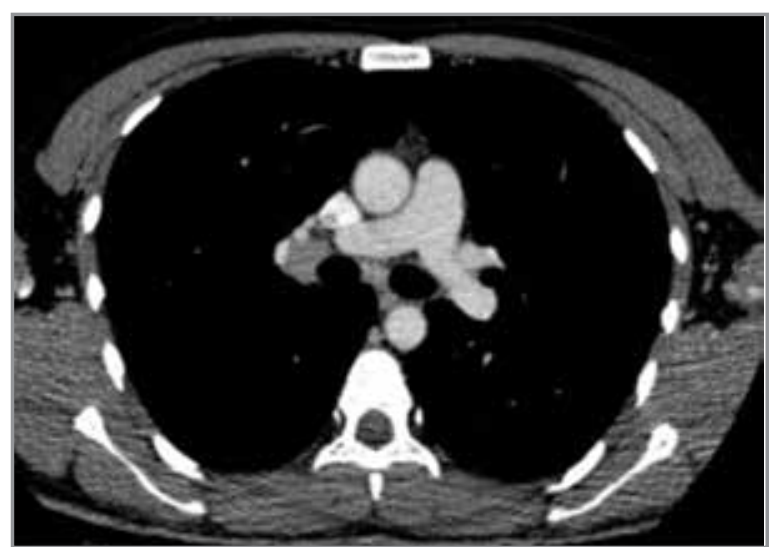

Resim 3. Hastanın başvurudaki toraks bilgisayarlı tomografisi.

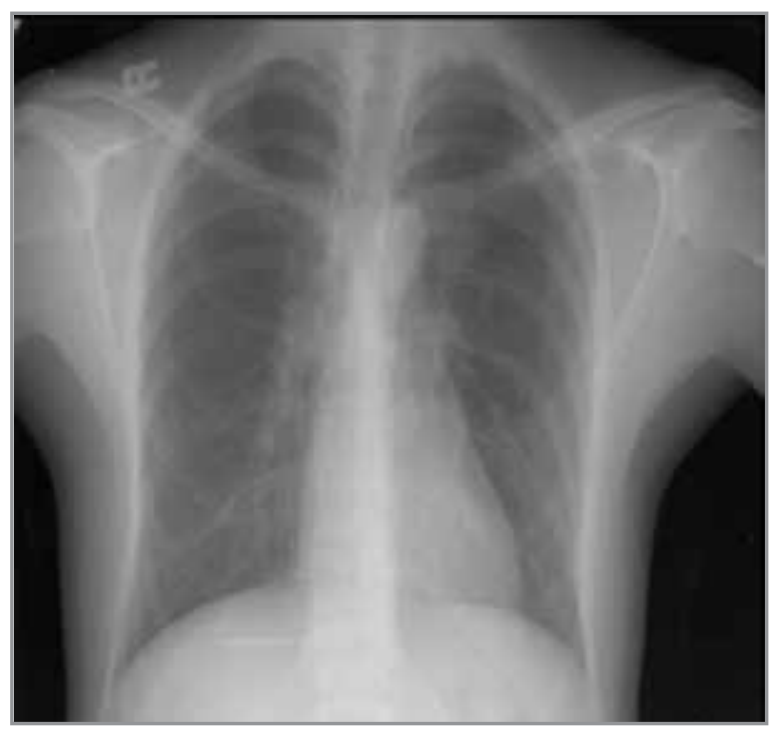

Resim 4. Başvurudan bir ay sonraki PA akciğer grafisi.

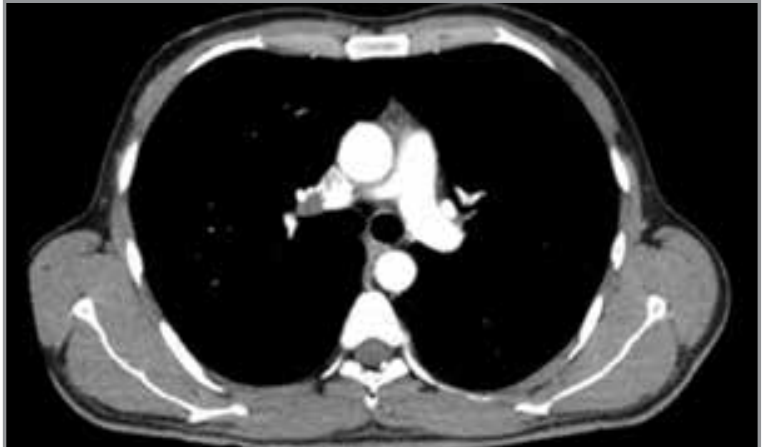

Resim 5. Hastanın bir ay sonraki kontrol toraks bilgisayarlı tomografisi.

nodunda progresyon saptanmadı (Resim 4,5). Genel durumu stabil olan hastaya üç ay sonrasına kontrol önerildi.

\section{TARTIŞMA}

KFH 1972 yılında ilk kez Kikuchi tarafından "retikülin hücreli hiperplazi" ve daha sonra da aynı yıl içerisinde Fujimoto tarafından "subakut nekrotizan lenfadenit" olarak tanımlanmış, genellikle servikal lenfadenopati ve ateşle seyreden bir hastalıktır (6). Tam patogenezi bilinmemekle beraber infeksiyöz bir ajana immün $T$ hücre ve histiyosit yanıtı ile meydana gelir. Tetikleyici ajanlar arasında EBV, human herpes virüs6 ve 8 , HIV, parvovirüs B19, paramiksovirüs, parainfluenza virüs, toksoplazma gelmektedir (7). Sitotoksik CD8+ T hücrelerin primer rol aldığı apopitotik hücre ölümü, sellüler imhada öncelikli mekanizmayı oluşturmaktadır (8). Histiyositler olayda güçlendirici olarak rol oynar. Apopitozis fas-fas ligand sistemi ile uyarılır. Morfolojik görünümü yaygın karyorekzis ve nükleer artıkların eşlik ettiği yama tarzında fokal nekrotik odaklar (apopitotik body) ve bu alanların etrafında çoğalan histiyositler, immünoblastlar, yer yer plazma hücreleri ve T lenfositleri ile karakterizedir. IFN- $\gamma$ ve IL-6'nın da olası rol oynayabileceği erkeklerde yapılan biyopsi ile KFH tanısı almış bir çalışma ile kanıtlanmıştır (9).

KFH öncelikle kadınlarda tanımlanmasına rağmen bizim olgumuzda da olduğu üzere erkek cinsiyette de görülebilir. Çoğu hasta 40 yaşından küçük olup Amerika Birleşik Devletleri (ABD)'nde çalışmalarda tanımlanmış ortalama yaş $30^{\prime}$ dur. ilk olarak iki ayrı Japon olguda tanımlanmasına rağmen tüm ırk ve etnik gruplarda görülebilir, nitekim ABD'de $88 \mathrm{KFH}$ olgusunu içeren bir çalışmada, olguların \%75'inin Kafkas ırkından olduğu görülmüştür (10). En sık pre- 
zentasyonu ateş ve servikal lenf nodu ile başvuran genç kadın hasta şeklindedir. Düşük şiddette, persistan ve yaklaşık bir hafta kadar devam eden ateş; bizim olgumuzda da olduğu gibi başvuru yakınmalarının \%30-50'sini oluşturmaktadır. Ateş ve lenfadenopati dışında eşlik edebilen diğer sistemik semptomlar; gece terlemeleri, mide bulantısı, kusma, yaklaşık kilonun \%10'unu bulan kilo kaybı, ishal olarak sıralanabilir (11). Bunların dışında ve daha az sıklıkla miyalji, artralji, göğüs ve karın ağrısı, abdominal lenfadenopatiye bağlı olabilecek hepatomegali ve splenomegali görülebilir (10). Hastamızda ateş ve lenfadenopatinin yanı sıra artralji-miyalji ve kilo kaybı da mevcuttu. Hastalık en sık servikal lenf nodu tutulumuyla tanımlanmasına rağmen; aksiller, epitroklear, inguinal, intraparotid, iliak, retrokrural, çölyak, peripankreatit ve nadir olmasına karşın olgumuzda da saptadığımız şekilde mediastinal lenf nodu tutulumuyla da prezente olabilir. Olgumuzdaki gibi genelde lenf nodu boyutu 1-2 cm civarında sert, düzgün yüzeyli ve mobildir. Nadiren daha büyük boyutlara ulaşabilir $(<7 \mathrm{~cm})(12)$. Aseptik menenjit, tremor-ataksi gibi akut serebellar semptomlar, panüveit, bilateral papiller konjunktivit, otoimmün hepatit, periferal nöropati, brakiyal nörit ile tanımlanmış nadir olgularda literatürlerde mevcuttur (13). Laboratuvar bulgularına bakıldığında genelde tam kan sayımında patolojik bulgu saptanmaz, ancak karakteristik özellik olarak lökopeni saptanabilir (14). Eritrosit sedimentasyon hızı $\% 70$ olguda $>60 \mathrm{~mm} /$ saat olabilir (15). Olgumuzda başvuru sedimentasyon hızı $55 \mathrm{~mm} / \mathrm{saat}$, periferik kan sayımında patoloji saptanmamıştı. Ateş ve lenfadenopati nedenleri araştırılan olguda serolojik çalışmalara bakıldığında ayırıcı tanı açısından tetkik edilmesi gerekli kollajen doku markırları (ANA, anti-ds DNA, ANCA) ve Rose Bengal testi negatif, HSV-1 IgM sınırda pozitif, EBVCMV, Brucella-Rubella-Toxoplasma PCR, HIV serolojileri negatifti. Göğüs hastalıkları pratiğinde lenf nodu ayırıcı tanısında ilk akla gelen tüberkülozla ilgili balgam ARB-Kültür ve TDT negatifti. Aile öyküsü sorgulandığında da indeks olgu saptanmadı. Hastalığın kesin tanısı lenf nodu biyopsisi ile konulmaktadır ve özellikle lenfoma gibi daha ciddi durumIarın ekartasyonu amaçlı muhakkak yapılmalıdır. En başta önerilen biyopsi şekli eksizyonel biyopsidir $(16,17)$. KFH'de mikroskobik inceleme bulguları; nodal yapıyı bozabilen parakortikal alanda koagülasyon nekrozuna sekonder bol miktarda karyorektik debrisler ve farklılaşmış histiyositledir. Perinodal infiltrasyon sıktır, kapsülde infiltre olabilir.
Koagülasyon nekrozu KFH tanısı için ön koşul değildir. Artmış mitotik aktiviteye sahip foküsler histiyosit, plazmositik monositler (immünhistokimyasal çalışmalarda CD68 +) immünoblastlar, lenfositler gibi farklı hücresel tipleri kapsar, ancak karakteristik olarak nötrofiller ve plazma hücreleri görülmez $(17,18)$. KFH'nin histopatolojik bulgularının SLE lenfadenitine çok benzemesi nedeniyle kendini sınırlayan bir SLE formu olduğu da öne sürülmektedir (19). Bizim olgumuzun patolojisinde yaygın histiyosit hücre infiltrasyonu, yer yer fokal nekrotik odaklar KFH ile uyumlu olarak saptanmıştı, SLE markırları ve periferik kan tablosu normal; klinik olarak SLE ilişkili semptomu olmayan hastada SLE düşünülmedi. Ayrıca atipik sitolojinin ve tek tip hücre infiltrasyonunun olmaması ile de lenfomadan ayrımı yapıldı. Genelde karakteristik histopatolojik bulgular lenf nodlarında tanımlanmasına karşın, cilt biyopsilerinde de değişken bulgular saptanabilir. Olgumuzda ateş, lenfadenopati, mediastinal lenf nodu tutulumları dışında herhangi bir tutulum saptanmamıştı.

KFH tedavisinde ise kanıtlanmış bir yöntem yoktur. Semptomlar ortaya çıktığında analjezik, antipiretiklerle semptomatik tedavi önerilir ve genellikle 1-4 ay içerisinde kendiliğinden geriler. Persistan ciddi semptomları olan hastalar glukokortikoidlerle ya da intravenöz immünglobulinlerle tedavi edilebilirler (20). Takip eden yıllar içinde SLE ortaya çıkma olasılı̆̆ı yüksek olduğu için semptomların yakın takibi gereklidir.

Klinik, laboratuvar ve patolojik bulgular beraber değerlendirildiğinde $\mathrm{KFH}$ tanısı koyduğumuz hastamızda lenf nodunun total çıkarılmasıyla, nonspesifik antibiyoterapi ve antiinflamatuvar tedavi ile yaklaşık 20 gün içinde semptomlarda anlamlı düzelme izlendi.

Sonuç olarak; ateş, lenfadenopati ve yüksek sedimentasyon hızı ile başvuran hastalarda göğüs hastalıkları pratiğinde daha sık karşılaştığımız malign lenfomalar ve tüberküloz gibi hastalıkların yanı sıra benign seyirli bir hastalık olan KFH da akılda tutulmalıdır.

\section{KAYNAKLAR}

1. Dorfman RF. Histiocytic necrotizing lymphadenitis of Kikuchi and Fujimoto. Archives of Pathology \& Laboratory Medicine 1987;111:1026-9.

2. Kikuchi M. Lymphadenitis showing focal reticulum cells hyperplasia with nuclear debris and phagocytosis: A clinicopathological study. Nippon Ketsueki Gakkai Zasshi 1972;35:379-80. 
3. Chamulak GA, Brynes RK, Nathwani BN. Kikuchi-Fujimoto disease mimicking malignant lymphoma. Am J Surg Pathol 1990; 14:514-23.

4. Turner RR, Martin J, Dorfman RF. Necrotizing lymphadenitis: a study of 30 cases. Am J Surg Pathol 1983;7:115-24.

5. García CE, Girdhar-Gopal HV, Dorfman DM. KikuchiFujimoto disease of the neck update. Annals of Otology, Rhinology \& Laryngology 1993;102:11-5.

6. Aslan V, Bildirici K, Eren Ö, Gülbaş Z. Kikuchi-Fujimoto Hastalığı: Olgu sunumu. Türkiye Ekopatoloji Dergisi 2001;7:46-8

7. Hudnall SD, Chen T, Amr S, Young KH, Henry K. Detection of human herpesvirus DNA in Kikuchi-Fujimoto disease and reactive lymphoid hyperplasia. Int I Clin Exp Pathol 2008; 1:362-8.

8. Iguchi KS, Hideo Yamane, Kazuo Konishi, Masahiro Takayama, Yoshiaki Nakai, Takayuki Nakagawa, Shigetaro Shibata, Keizo Nishimura, Hiroyoshi. Apoptotic cell death in Kikuchi's disease: a TEM study. Acta Oto-Laryngologica 1998; 118:250-3.

9. Kubota M, Tsukamoto R, Kurokawa K, Imai T, Furusho K. Elevated serum interferon and interleukin-6 in patients with necrotizing lymphadenitis (Kikuchi's disease). Br J Haematol 1996; 95:613-5.

10. Dorfman R, Berry G. Kikuchi's histiocytic necrotizing lymphadenitis: an analysis of 108 cases with emphasis on differential diagnosis. Semin Diag Pathol 1988.

11. Kuo TT. Cutaneous manifestation of Kikuchi's: histiocytic necrotizing lymphadenitis. Am J Surg Pathol 1990;14:872-6.
12. Kuo TT. A clinicopathologic study of 79 cases with an analysis of histologic subtypes, immunohistology, and DNA ploidy. Am J Surg Pathol 1995;19:798-809.

13. Kapoor S. Rare Complications of Kikuchi's Disease: Beyond Pain Control. The Korean Journal of Pain 2012;25:281-2.

14. Song JY, Cheong HJ, Kee SY, Lee J, Sohn JW, Kim MJ, et al. Disease spectrum of cervical lymphadenitis: analysis based on ultrasound-guided core-needle gun biopsy. I Infect 2007; 55:310-6.

15. Norris AH, Krasinskas AM, Salhany KE, Gluckman SJ Kikuchi-Fujimoto disease: a benign cause of fever and lymphadenopathy. Am J Med 1996;101:401-5.

16. Mannarà GM, Boccato $P$, Rinaldo A, La Rosa F, Ferlito A. Histiocytic necrotizing lymphadenitis (Kikuchi-Fujimoto disease) diagnosed by fine needle aspiration biopsy. ORL 1999;61:367-71.

17. Tsang WY, Chan JK. Fine-needle aspiration cytologic diagnosis of Kikuchi's lymphadenitis: a report of 27 cases. Am J Clin Pathol 1994; 102:454-8.

18. Ohshima K, Karube K, Hamasaki M, Makimoto Y, Fujii A, Kawano R, et al. Apoptosis-and cell cycle-associated gene expression profiling of histiocytic necrotising lymphadenitis. Eur J Haematol 2004;72:322-9.

19. Papaioannou G, Speletas M, Kaloutsi V, Pavlitou-Tsiontsi A. Histiocytic necrotizing lymphadenitis (Kikuchi-Fujimoto disease) associated with antiphospholipid syndrome: case report and literature review. Ann Hematol 2002;81:732-5.

20. Lin D, Villegas $M$, Tan P, Wang $S$, Shek L. Severe Kikuchi's disease responsive to immune modulation. Singapore Med J 2010;51:e18-21. 